\title{
A kínai diaszpóra
}

\section{The Chinese Diaspora}

\section{Összefoglalás}

A kínai diaszpóra a harmadik legnagyobb a világon, száma mintegy 40 millió fót tesz ki, ám kialakulásának sajátosságai és a több mint egy évszázados kínai politika következtében az anyaországhoz fúzôdô viszonya szorosabb a nála nagyobb számú diaszpóráknál. A kínai diaszpóra talán legfontosabb sajátosságai közé tartozik, hogy az anyaországhoz fúzôdó kulturális, identitásbeli vagy származási kapcsolat nem csupán a befogadó országok kisebbségi politikájában játszik szerepet, hanem maga a Népköztársaság is ezen jellemzók mentén határozza meg a közösség tagjait. A másik meghatározó tulajdonság, hogy a két évezrede zajló kivándorlás legfôbb mozgatórugói a kereskedôk voltak, még azon idôszakokban is, amikor a brit birodalomban betiltott rabszolga-kereskedelem munkaerôhiányát pótló kulik határozták meg az emigrációt, vagy amikor a kivándorlás elsôsorban a diákokat és az értelmiségieket jelentette 1978 után. Az ebből fakadó folytonos gazdasági térnyerés pedig mára Kína számára a külkapcsolatok és a tôkebeáramlás egyik meghatározó bázisává, forrásává vált.

Journal of Economic Literature (JEL) kódok: F22, F38, J15, J61, K37, O24, Z10

Kulcsszavak: kínai diaszpóra, kivándorláspolitika, kisebbségpolitika, kínai történelem

\section{Summary}

The Chinese diaspora is the third largest one in the world, consisting of approx. 40 million people. Due to the characteristics of its evolution and to the relevant centurylong Chinese policy, its relations with the mainland is tighter than those of other, more populous communities. Perhaps one of the most important features of the Chinese diaspora is that in addition to the host countries' minority policies, relationship

Dr. Koudela PÁL PhD, fôiiskolai tanár, Kodolányi János Főiskola (pkoudela@ yahoo.com). 
with China based on culture, identity or provenance also plays a role in China, as the motherland defines the community along these dimensions. The other defining feature is that the principal driving forces of emigration, which has been going on for two thousand years, were merchants; even in periods when emigration was predominated by coolies who made up for labour shortages caused in the British Empire by the ban on slave trade; or when emigration primarily meant the relocation of students and intellectuals after 1978. The resulting continuous economic expansion of the diaspora has become one of the main bases and sources of foreign relations and capital inflow for China.

Journal of Economic Literature (JEL) codes: F22, F38, J15, J61, K37, O24, Z10

Keywords: chinese diaspora, emigration policy, minority policy, chinese history

\section{BEVEZETÉS}

Kína számára a nemzetállam egységének kérdése ma két látszólag eltérô területen mutatkozik meg a leglátványosabban - a napi hírekben is a legfeltúnóbb módon megjelenítve. Az egyik a hatalmas területú ország etnikai kisebbségeinek kérdése, melyek közül talán Tibet, a tibetiek függetlenségi törekvései, a számukra biztosított autonómia és jogok, a konfliktusok sokszor vitát kiváltó kezelése, a történelmi sérelmek kérdése, illetve a dalai láma nemzetközi szerepvállalása és a belôle fakadó nemzetközi feszültségek a legismertebb. Mára persze sokat hallunk az iszlám, az ujgurok és más vallási vagy etnikai kisebbség helyzetérôl is, így tehát a kérdés akár úgy is felmerülhet, hogy vajon a kisebbségek kezdik egyre jobban feszegetni a nemzetállamon belüli lehetôségeik határait, vagy Kínában válik egyre inkább meghatározó politikai ideológiává a nacionalizmus. A másik terület, amely legalább annyira fontos része a modern kori nemzetállam-építésnek, a külföldön élook közössége. A kínai diaszpóra méretét és fơként jelentôségét tekintve eltér a többitôl, jelentôs szerepet játszik a gazdaság stratégiai felépítésében, s ami még fontosabb, befolyásolja az anyaország, a Kínai Népköztársaság aktuális politikáit is (To, 2014).

Elena Barabantseva, a Manchesteri Egyetem kínai nemzetiségi politikával és bevándorlással foglalkozó szakértője könyvének bevezetőjében pontosan rávilágít, milyen nagy mértékben összefonódik a kínai politikai döntéshozatalban a diaszpóra és az etnikai kisebbségek kérdése (Barabantseva, 2012:2-4). A történelem tovább él: akár imperialista, republikánus vagy szocialista államformában, de az ország egyes területeinek a sorsát - legyenek akár belsố perifériák, mint Tibet, Belsô-Mongólia vagy a Hszincsiang-Ujgur Autonóm Terület, vagy külsôk, mint Hongkong és Makaó - régen és most is elsôsorban Belsô-Kína vagy a han kultúra dominanciája határozza meg (Potter, 2007:240). A múltban Kína birodalmi terjeszkedése során a határterületekben csupán a katonai vagy politikai szervezési feladatot látta, az ott élő vagy azon túlról fenyegetô népekkel idônként meg kellett küzdenie -, mint a Tarim-medence nomád 
népeivel, nagyon is erôszakosan -, s éppen ezért mindez csupán annak állami egységét alakítgatta. Hasonló a helyzet most is, amikor akár a területek autonómiája kerül szóba, akár stratégiai vagy gazdasági szempontok állnak a középpontban, Kasmírtól egészen a Dél-kínai-tengerig: elsôsorban az integráció az, amire mindez hatással van, s fordítva, az állami integráció az, ami a felmerülố konfliktusoknak a központi elemét adja. A területek népességének etnikai hovatartozása, milyensége - valamint éppen ezen disztinkció, vagyis a párhuzamos narratívák megkülönböztetése mentén haladva, a határon túl éló kínaiak tömegei is - csupán a nemzet fogalmának szélén jelennek meg, ezért igen alkalmasak annak körülhatárolására. Ez az a szempont, ami az állami és a nemzeti definíciót megkülönbözteti, s mely az utóbbi identitásszemléletú értelmezéseként Kína diaszpórapolitikájában is sajátságos szerepet játszik.

\section{A KÍNAI DIASZPÓRA MEgHATÁrozÁSA}

Elsốként azt kell pontosítanunk, kik is tartoznak a diaszpórába (Charney et. al., 2003; Yong, 2014; Christiansen, 2003; Freedman, 2000; Kenley, 2003; Kuah-Pearce-Davidson, 2008; Lim, 2013; Rae-Witzel, 2008; Lever-Tracy et. al. 1996; Tan, 2012). Habár át- meg áthatja a politikai diskurzust a sinocentrikus, pontosabban a han-centrikus szemlélet (Barabantseva, 2012b:78), a Kínához tartozó területeken élố nemzetiségeket akkor sem tekintjük idetartozónak, ha bármilyen más szempont mégis a többségi társadalomtól való különválasztásukat indokolná, vagy ha a kínai politika másként kezeli is ôket. Ugyancsak nem tekinthetố a diaszpóra részének Makaó, Hongkong, sốt Tajvan lakossága sem. Az elôbbi kettô államforma szerint is konvergál Kínával, pontosabban 1997 és 1999 óta Kína része; Tajvan ugyan önálló államként definiálja magát, de az ENSZ, és ami fontosabb, Kína ezt nem ismeri el. Ez utóbbi nem szerzói állásfoglalás, hanem a népköztársaság azon politikájára vonatkozó szempont, mely a tengerentúlon éló kínaiakat hivatott kezelni, s amely nem sorolja közéjük az elóbbi lakosokat, odasorol viszont mindenkit, aki nem él az elóbbi területeken, viszont akár a legkisebb mértékben is kötôdik származásához (Barabantseva, 2005:1). Ez tehát magának Kínának az egy ország, két rendszer - vagy mára leginkább az egy ország, sok rendszer irányelvéből - következik (Zhu, 2012), de legalább ennyire fontos, hogy öszszhangban van azzal a történeti képzôdménnyel, amit a han-centrumok és a belsố és külsô perifériák rendszerének nevezhetünk (Rigger, 2014). Harminchárom különbözố terület egységét ugyanis sem föderatív, sem egységállamnak nem tarthatjuk, hanem leginkább a kettô ötvözetének.

A diaszpóra szó, habár eredetileg csupán a Júdeából elúzött zsidó közösségeket jelentette, a kétezres évekre általánosan használt kifejezés bármely államalkotó nemzet más országokban éló közösségeire. A kifejezés azonban ennél is többet takar, s az sem véletlen, hogy itt a „külföldön éló kínaiak” helyett általában az elóbbi kifejezést állítjuk a középpontba, s még akkor is a kibôvített értelmet tulajdonítjuk neki, ha idônként a külföldi, külföldön élố vagy az emigráns kifejezéseket alkalmazzuk. ${ }^{1}$ Azzal ellentétben ugyanis nem csupán a Kínában született, de külföldön élố népességet fedi le, hanem azok is beletartoznak, akik születés vagy származás révén tartják magukat kínainak 
(Brubaker, 2005:5). Erre különös okunk van, ugyanis a kínai diaszpóra olyan közösségeket képez, melyeknek viszonya az anyaországgal egyedi, s a kapcsolat különlegessége a sokadik generációkban is érvényesül, valamint amelyre a Népköztársaságban konkrét migrációs politika is irányul. Ez a különleges viszony inspirálta Dino Patti Djalalt, volt amerikai nagykövetet, volt külügyminiszter-helyettest, hogy az indonéz diaszpóra fogalmát is újra és újra átfogalmazza (Muhidin-Utomo, 2013:5; Indonesia Diaspora Network).

Általánosságban is lehet indok a diaszpóra tágabb értelmezésére, William Safran négyet is felsorol: ilyen pl. a kollektív memória vagy mítosz, amit egy közösség a szülőföldről fenntart, s ami igen erős köteléket jelent. De legalább ennyire fontos lehet, ha a származási helyüket igazi vagy ideális otthonnak, lakóhelynek tartják akár olyanok is, akik már generációk óta nem élnek az adott országban, ahonnan felmenôik származtak, s ahová ôk egyszer mégis visszatérni kívánnak. Végül is ez volt az álija értelme évezredeken át, még ha 1882-ig csupán elképzelés maradt is. Harmadszor: azok, akik távol élnek származási helyüktől, gyakran érzik azt, hogy felelósséggel tartoznak, vagy csak egyszerúen szeretnének hozzájárulni hajdani hazájuk fejlődéséhez, biztonságához. Így tettek pl. azok a kínaiak, akik az aranyláztól kezdve vándoroltak Amerikába, s akik ugyan semmilyen segítséget nem kaptak a Csing-Kínától, mégis abban reménykedtek, amikor az ô segítségüket kérte az anyaország, hogy hozzájárulásukkal megerôsödve, az majdcsak hozzájárul az Egyesült Államokban való elfogadtatásukhoz. Nem tehettek mást tehát, lelkesen segítettek hajdanvolt hazájuknak (Liu, 2002:10).

Végül, akár közvetlenül, akár csak közvetve, de a származás befolyásolja az adott személyiséget, sôt akár a csoportidentitást is (Safran, 1991:83-84). A 16. századtól jelentôs kínai vándorlás indult meg Indonézia, Thaiföld, általában a délkelet-ázsiai térség felé, az évszázadok során pedig egy szubsztantív gazdasági, az ún. Bambusz Hálózat jött létre, melynek alapját a kiterjedt, transznacionális családi kapcsolatok képezik. Különösen jelentôs növekedésnek indult a képződmény a kommunista Kína kikiáltása után, elsôsorban azon menekültek révén, akik az akkor már meglévô rokoni és baráti kapcsolatokat aknázták ki, hogy a délkelet-ázsiai országokban menekültként vagy más módon letelepedhessenek, a helyi gazdaságba integrálódhassanak (Weidenbaum-Hughes, 1996:8, 23-28). A más ázsiai országokban múködó kínai cégek, a kínai tôke jelenléte, illetve a Kínával, az anyaországgal való kapcsolattartás jelentôsége oly nagymértékú és intenzív a diaszpóra körében, hogy egyes szerzôk egyenesen „Kínai Nemzetközösségnek” nevezik ezt a gazdasági hálózatot (Kao, 1993). Egyfelől tehát a rendszer igen jelentôs szerepet játszik Malajzia, Indonézia, Thaiföld, Vietnám, a Fülöp-szigetek és Szingapúr magánszektorában, és az anyaország gazdaságát is jelentôsen befolyásolják a hazautalások, illetve Teng Hsziao-ping gazdasági nyitása óta általában is jelentôs fejlódésnek indultak az anyaországgal való intenzív gazdasági kapcsolatok. Másfelôl viszont, habár többnyire közepes méretú, családi vállalkozásokról van szó, mégis egy szervezett bürokráciaként, konfuciánus hagyományára épülve múködnek, tehát akár egy olyan látens gazdaságról is beszélhetünk, amely jelentóségében és szervezôdésében is regionális szintú. A családi kapcsolatokon keresztül zajló finanszírozás és kereskedelem gyors, és a tôkeáramlást az esetleges regionális szabályozások, koráb- 
bi korlátok sem gátolták. Így valójában a Bambusz Hálózatról szólva a regionalizáció egy korai formáját láthatjuk.

Az 1997-es krízist követóen az egyes kormányzatok igyekeztek a Bambusz Hálózat és hasonló informális gazdasági kapcsolatok szerepét háttérbe szorítani, és a valós szerzôdéseket, a formális gazdasági bürokráciát propagálni helyettük (Chen, 2004:205). Mindez a korábbi szabályozási rezsimek felszámolásával hozzájárult az új kapcsolatrendszerek kialakulásához, ám ugyanakkor jogosan tekinthetôk egyfajta előzménynek is a regionális kapcsolatok szemszögéból. Kína gazdasági növekedése következtében azonban a befektetői helyzet megfordult, s mára a még mindig meglévô kapcsolatrendszer múködik az egyik legnagyobb közvetítôként a külföldi beruházások segítésére. A Bambusz Hálózat nyitott rendszer, beágyazódik a helyi erőforrásokba, felhasználja az információkat, lokális kapcsolatokat, sôt akár új praktikákat is képes tanulni, amivel elősegíti további növekedését és rugalmasságát. Ha mindezt figyelembe veszszük, akkor indokolt a diaszpóra-interpretáció többrétú kibôvítése, de ami ennél is fontosabb, megérthetô, hogy Kína teljesen egyedi módon értelmezi a máshol élók közössége s az anyaország közötti kapcsolatot, s létesített éppen ezért az emigrációra vonatkozó sajátos szabályozást.

\section{A DIASZPÓRA SZÁMA ÉS KIALAKULÁSA}

A fenti értelmezés azonban egy jelentôs nehézséggel is küzd, s ez magának a diaszpórának a számszerúsítése. Éppen a kötôdés megléte és a származás/örökség feltételezése között húzódik a leghomályosabb vonal, s habár rengeteg becslés lát napvilágot, fôként a sajtóban (Xinhua, 2012), de akár szakértôi elemzésekben is, amelyek sokszor szintén a sajtót veszik alapul (Liu-Du, 2014; Wang, 2012:1), ${ }^{2}$ ezek mögött nem áll sem forrás, sem módszertani értelmezés, így hitelességük kérdéses. Ráadásul nem állnak rendelkezésre egyszerú statisztikák, amelyeket a fogadó országok bevándorlási hivatalai, népszámlálásai rögzítenek a születési vagy utolsó tartózkodási hely szerint. Ilyen tágan értelmezve pl. a legnagyobb diaszpóra a világon még csak nem is az indiai vagy kínai, hanem a német, melynek nagyságrendjét Dudley Poston 95 millióra teszi. Az ó értelmezésében a kínai diaszpóra nagyságára nézve, a maga 40,3 milliós méretével csupán a harmadik helyen áll az írek mögött (Poston-Wong, 2014:27). Míg azonban a két legnagyobb diaszpóra csupán a 18. századtól eredeztethetô, a kínai kétezer éves múltra tekint vissza.

Talán a legfontosabbak közöttük mindenekelôtt azok a kereskedó kivándorlók, akik évszázadok óta utaztak külföldre, hoztak létre üzleteket, s akik már csupán alapvetô érdekeik miatt is fenntartották a kapcsolatot Kínával. De büszkeség és identitásôrzés is közrejátszott abban, hogy ilyen hosszú idôn keresztül megmaradt a kapocs, s volt ez annál erôsebb, minél sikeresebb az új, külföldön múködô vállalkozás (Wang, 2003:5). A kereskedôk azonban gyakran hazatelepültek, majd késôbb újra megpróbálkoztak egy új vállalkozást beindítani ugyanabban az országban, esetleg másutt. Az is előfordult, hogy a hazatelepült családban felnövő gyerekek próbálták meg újra azt, amit a szüleik is néhány évvel korábban. A kínai kereskedők többsége a mai Kína déli terü- 
leteirôl vándorolt, fôkként Délkelet-Ázsia országaiba, s a gyakori oda-vissza vándorlás nem is csupán egyszerú migrációs csatornát, hanem egy sûrú szövevényét hozta létre a migrációs rendszereknek a két terület között.

Erre példa annak a huszonnégy éves férfinak, Meleciónak az esete is, aki hatéves kisfiával 1841-ben vándorolt a Fülöp-szigetekre Kína délkeleti, Fucsien tartományából. A kisfiút Co Giok Kuannak hívták, s az apja is átélte ugyanezt az élményt, mikor gyermekként a Fülöp-szigetekre költözött, majd haza Kínába (Pan, 1990:153-154). Melecio, aki egy spanyol bevándorló és egy Fülöp-szigeteki házasságából született, ácsként kezdett dolgozni Manilában, és felesége is vegyes házasságból született, ôsei Venezuelából, Japánból és Kínából származtak. Fia a José keresztnevet s annak változatát, a Cojuangco nevet kezdte használni. Az immár keresztény José is ácsként dolgozott, vállalkozása már a család egyre hatalmasabbá növekvô cukor- és rizsültetvényeivel is kiegészült, késôbb pénzkölcsönzésbe is kezdett, ami szintén jelentős vagyon felhalmozásához segítette.

José megházasodott, gyermekeik születtek, s azoknak is születtek gyermekeik. Az egyik unokát szintén Josénak hívták, aki már a családi birtokok központjának, Tarlac tartománynak lett a parlamenti képviselője. A Cojuangco klán egyre nagyobb hatalmat birtokolt, s a Fülöp-szigeteki politikába is beszivárgott; Marcos legbizalmasabb köréhez tartoztak, s mára az egyik leghatalmasabb család lett a délkelet-ázsiai országban, bankok, kereskedóházak és az egyik legnagyobb cukorültetvény, a Hacienda Luisita birtokosai (Putzel, 1992:94). José unokájának hat gyermeke született Demetria Sumulongtól, Rizal tartomány szenátorának lányától, s az egyik lányuk, Corazon Aquino (Skard, 2015:163) a Fülöp-szigetek s egyben Ázsia elsố nôi köztársasági elnöke lett 1986-ban. Benigno Aquino III, aki 2010-tól 2016-ig az ország elnöke volt, az ô fia. Ami a történetben különösen érdekes, hogy bár a hidegháború elejétôl kezdve Kína és a Fülöp-szigetek az ellenkezô oldalon állt, mindez nem gátolta ôket, hogy kereskedelmi és bilaterális kapcsolatokat építsenek ki, különösen 1986 után.

Mindebben fontos szerepet játszott Corazon Aquino, aki sokszor hangsúlyozta, hogy mindezen kapcsolatokban milyen nagy jelentôsége van az ô kínai származásának (Baviera, 2012:1). De kínai a nagyapja Rodrigo Duertének is, szintén Fucsienból, s az ô politikájára is rányomja bélyegét kínai kötôdése (Woody, 2016), s ezt nem is titkolja (Xinhuanet, 2016). Ám bárhogyan értelmezzük a fentieket: valódi, generációkon áthúzódó kapcsolatrendszernek vagy a mitikus múltban gyökereket keresố emlékezetnek, esetleg a pillanatnyi érdekeket szolgáló kifogásnak, a családon keresztüli kapcsolatrendszer a két ország között mindenképpen létezô entitás. És bárhogyan értékeljük az elsố nổi elnök családjának „gazdasági hátterét”, a modern demokrácia alapjait mégiscsak ô teremtette meg a Fülöp-szigeteken, a húszéves diktatúra felszámolásával.

Egy másik példa az 1860-as években Kuangtung tartomány Meizhou városából kivándorló Seng Saekhu története. A fiatalember szüleivel és bátyjával indult Sziámba, ám hamarosan egyedül maradt, mert a család többi tagja hazatért. Chanthaburiban letelepedve fóadóbérló lett, feleséget is talált magának, s mikor 1900-ban a földbérlet lejárt, Bangkokba költöztek, ahol már kereskedőként dolgozott. Elsô házasságából 1890-ben született legidôsebb fia, Csiang szintén thai lányt vett feleségül, legidôsebb 
fia, a növekvô Kína-ellenes érzület hatására, 1938-ban felvette a Sak Shinawatra thai nevet, s hamarosan a család többi tagja is követte példáját, ezzel nagyban elôsegítve beilleszkedésüket Thaiföld társadalmába. Idôvel a katonaság vezérkarába jutott, tábornoki rangig vitte, míg harmadik fia, vagyis Seng dédunokája már a hadsereg főparancsnoka lett. Csiang második fia, Loet Shinawatra 1919-ben született, s szintén egy kínai bevándorló lányát vette feleségül. A felesége anyja azonban egy thai hercegnô volt a királyi család egy szerényebb ágából. Loet Shinawatra politikai pályára lépett, 1968-ban Csiangmaj parlamenti képviselóje lett belóle, és az akkori Szabadelvú Párt elnökhelyettese. 1976-ban elhagyta a politikai pályát, narancstermesztéssel, autókereskedéssel és egyéb kereskedelmi tevékenységgel kezdett foglalkozni. (PhongpaichitBaker, 2004:26-34). Mire Loet gyermekei, Thaksin Shinawatra és Yingluck Shinawatra 1949-ben és 1967-ben megszülettek, a család már a legbefolyásosabb és leggazdagabb famíliák közé tartozott Thaiföldön. Thaksin 2001-ben foglalta el az ország miniszterelnöki posztját. Még elnöksége idején meglátogatta Kínában családja egykori szülővárosát, Meizhout. Kuangtung kormányzóságának köszönetet mondva így nyilatkozott: „Amikor a kínai emberek látják, hogy egy thai vezető és számtalan thaiföldi vállalkozó jön Kínába, leróni tiszteletét a hely elôtt, ahol valaha az óseik éltek, akkor majd megértik, hogy a thaiok és a kínaiak egy családból származnak, és rokonaik egymásnak” (China Daily, 2005). Thaksin több alkalommal is hangsúlyozta kínai származásának fontosságát, s ezzel összhangban igyekezett a két ország kapcsolatait erôsíteni; ô vezette talán a legnagyobb delegációkat a „Bao Fórum Ázsiáért” rendezvényeire. Kína válasza sem maradt el: rögvest létesítettek egy kínai kulturális és nyelvi központot a Thaiföld északi részében lévô Mae Fah Luang Egyetemen, s egyezményt írtak alá, melyben ötvenmilliárd dolláros bilaterális kereskedelmi kapcsolatot ígértek 2010-re (Kurlantzick, 2007:126).

A migrációs rendszerek bonyolult történeti folyamatok elegyeként forrnak ki jelenkori állapotukra, s különösen így van ez egy kétezer éves múltra visszatekintő, negyvenmilliós diaszpóra formálódásánál. Az 1933-as, a rabszolgaságot betiltó brit törvény az egész birodalomban lehetetlenné tette a rabszolgatartást, a velük való kereskedelem pedig már korábban, 1907 óta tilos volt. Az 1811-et követô fél évszázadban 1600 rabszolgaszállító hajót fogott el a brit birodalom haditengerészete által akkor életre hívott Nyugat-Afrika Hajóraj, s engedte szabadon az azokon szállított foglyokat. Igaz, hogy eleinte igen lassú volt az az öt hajó, amivel az egész nyugat-afrikai partvonalat ellenôrizni igyekeztek, de az 1850-es évektôl jóval hatékonyabbá vált, hiszen addigra már huszonöt hajó és kétezer tengerész szolgált a testület kötelékében. Az ezer afrikai tengerésszel is megtámogatott alakulat 150 ezer rabszolgának eladott nyugat-afrikait engedett szabadon az elfogott hajókról, s ennek következményei széles körúek voltak: többek közt az is, hogy az amerikai rabszolgák egynegyedét ebben a késôi, már az abolicionizmus által átjárt idôszakban hurcolták el (Sherwood, 2007:116-117).

A számunkra most fontosabb következmény azonban a képzetlen munkaerô hiányának egekbe szökő mértéke a hajdani brit, majd a francia, portugál és holland gyarmatokon. A rabszolgaság eltörlését követó évszázadban ezt az igényt elégítette ki a kínai és indiai kulikat foglalkoztató munkaerôpiac kialakulása. A kínai kulik dolgoz- 
tak aranybányákban, vasútépítkezéseken, a háztartásokban és mindenhol, ahol olyan munka akadt, amit mások nem végeztek el. Ekkortól indult meg a kivándorlás Kínából a nyugati országokba, ekkor jelentek meg elôször kínai munkások Kaliforniában, ahol az 1870-es évekre már a szakképzetlen munkaeró egynegyedét tették ki (Pan, 1990:94). Ennek eredménye a nyugati világban meginduló általános fordulat is, mely az ázsiai bevándorlók ellen irányult, majd általában a bevándorlás kvótákhoz kötött jellegú szabályozásának elterjedésében kulminált. Elsô jelentős lépése mindennek az Egyesült Államokban beiktatott 1882-es, a kínaiakat kirekesztô törvény volt (Koudela, 2013).

Habár a kereskedók is gyakran visszatértek Kínába, a kulik a legtöbb esetben eleve csak határozott idejú munkákat kaptak, s pl. az 1880-as évektól Amerikából még azokat is kitoloncolták, akik már évek óta ott éltek. Ők tehát folyamatos, intenzív kapcsolatban maradtak az anyaországgal - még ha sokszor csak kényszerból is. Velük szemben egy egészen más típusú kivándorlás indult meg a Csing-dinasztia s vele együtt a Kínai Birodalom 1911-es összeomlásával. A huszadik század eleji kaotikus állapotok elől menekülők, a korábbi kivándorlókkal szemben, általában magasabb végzettségúek voltak, és ritkán tértek haza. De ha nem is volt iskolájuk, azt mindenképpen igyekeztek megszerezni, s a kínai kultúrát, az ahhoz való hozzájárulást ezzel is erôsíteni. Többségük a délkelet-ázsiai országokba vándorolt, s követte óket tanárok egész serege egészen az 1950-es évekig, hogy a gyerekeiket kínai nyelvre, hagyományokra és történelemre tanítsa (Poston-Lou, 2007).

A kínai kultúra ápolásának modern, nacionalizmusba ágyazódó igénye s az anyaországhoz való szoros emocionális kötôdés az előbbi típussal jelent meg a kínai diaszpóra történelmében. A huszadik század közepe, a második világháborút követô enyhülés a migrációs politikákban azonban jelentôs változást hozott az etnikai integrációban is. Amerika, majd sorra Kanada és Ausztrália is átalakította a bevándorláspolitikáját, és fokozatosan eltörölték a diszkriminatív szabályokat. Nyugat-Európa országai, majd a rendszerváltások környékén Közép-Európa államai is, legalább közvetve, serkenteni kezdték a kínai bevándorlást. Ezzel párhuzamosan indult meg a korábban DélkeletÁzsiába kivándorolt kínaiak továbbvándorlása nyugati országokba. Eme mozgás hátterében azonban más is rejtôzik. A kínai bevándorlók ekkor már jó ideje felülreprezentáltak voltak a délkelet-ázsiai országok kereskedelmében, gazdasági túlsúlyuk gyakran keltett visszatetszést az ôslakosokban (Pan, 1990:226). Mindez oda vezetett, hogy az egyes államok vezetése sorra korlátozni kezdte lehetôségeiket az egyes gazdasági szektorokban; elsôként Thaiföld és a Fülöp-szigetek tett így, majd Indonézia és Malajzia is követte példájukat, s az érvényesülni vágyó bevándorlók számára nem maradt más lehetôség, mint továbbállni a lehetôségeiket ekkor már nem korlátozó nyugati országokba (Poston-Wong, 2014:8).

A kínai kivándorlás eme negyedik formája tehát csupán egy új jelenség, és azok, akik továbbvándoroltak, ugyanúgy kereskedők, mint az elsôként leírt típushoz tartozó, kétezer éve folyamatosan emigrálók, ám napjainkban s feltehetốen a közeljövôben is meghatározó lesz a helyhez kötô integráció hiánya s az ebból fakadó továbbvándorlás. A kínai diaszpóra közösségei elképesztô mértékben mobilisak, ezt reprezentálja a ke- 
let-európai bevándorlók példája is. Nyíri Pál beszámolóiból egyértelmúen kiviláglik, hogy itt egyik ország, így Magyarország sem végső állomás számukra, csupán az éppen elérhetố legalkalmasabb hely az életvitel javítása, a gyarapodás vagy fejlődés szempontjából. A magyarországi kínaiak egy része pl. Oroszországból érkezett, s 1992-ben, amikor megszigorítottuk a tartózkodási engedélyek elbírálását, sokan újra visszatértek oda. A legtöbb hazánkban élố kínai számára azonban már az elsô évektốl a nyugati országok jelentették a további célpontot: jobb kereskedési feltételeket szerettek volna biztosítani maguknak, s jobb iskolákat a gyerekeik számára (Nyíri, 2003:165-166).

A kínai diaszpóra 1980-ban 27 millió fốt számlált, 1990-re azonban már 37 millióra nôttt. A növekedés ezután globálisan megállt egy évtizedre; de kisebb mértékben tovább folytatódott a nyugati országokban, s az enyhe csökkenés az egyébként többségüknek otthont adó délkelet-ázsiai országokból történố elvándorlás miatt következett be. Míg a diaszpóra 1990-ben négyszerese volt a negyven évvel korábbinak (Poston-Yu, 1990), 2001-ben már egymillióval kevesebb, 36 millió kínai élt a világ 143 országában; 2011-ben viszont már 149 ország osztozott a 40 milliónál is nagyobb kínai diaszpórán. A 2000-es évtizedben a növekedés tehát újraindult; 2011-ben azonban több mint 70 százalékuk még mindig Ázsia országaiban élt; ez az arány 2001-ben még 75 százalék, 1980-ban pedig 90 százalék volt. 2011-ben is, akárcsak a korábbi évtizedekben, a legtöbb kínait befogadó ország Indonézia volt, ahol akkor nyolcmillióan éltek, s ez a teljes diaszpóra húsz százalékát tette ki. Ezt követte sorrendben Thaiföld, majd Malajzia. A kínaiak ugyanakkor legnagyobb arányban Szingapúr népességében vannak jelen, ahol 2011-ben 53 százalékot tettek ki (Poston-Wong, 2014:10-14).

\section{A NéPKÖZTÁrsaság VISZONYA A DIASZPÓRÁHOZ ÉS A GAZDASÁGHOZ}

A mindenkori állami politika nem új kérdése, hogy miképpen viszonyuljon a határon túl élôkhöz, legyenek azok csak nemrégiben kivándorolt alkalmi munkások, kereskedốk, vagy akár generációk óta máshol élô, esetleg már több országot megjárt családok, akik mégis ôrzik identitásuk részeként kínai származásukat. Van egy közös eleme az idôk folyamán változó szemléletnek, és ez a devizabeáramlás serkentésének igénye, legyen az hazautalás vagy külföldi tôkebefektetés. Mint láttuk, a legnagyobb számban Délkelet-Ázsiában élnek kínai, illetve kínai származású emigránsok, tehát a népköztársaság számára alapvetố jelentôségú, hogy ezekkel az országokkal baráti viszonyt tartson fenn, kétoldalú megállapodásokat kössön, és serkentse a diplomáciai kapcsolatok fejlôdését. Ez azonban sokszor ütközik nehézségbe a térségben alkalmazott egyéb politikái miatt, így pl. a Dél-kínai-tenger területi vitái inkább okoznak feszültséget a régióban, mint vezetnek harmóniához. Az érintett országok ráadásul leginkább egységesen lépnek fel az ASEAN nevében Kínával szemben, s ebben a pacifikus térség befolyásos államai is megerôsítik óket, különösképpen a geopolitikailag is érdekelt Egyesült Államok (Huisken, 2016).

Egy másik dilemma Kína számára, hogy a diaszpóra tagjainak jelentôs része már nem kínai állampolgár, ugyanakkor problémákkal terhes a kettôs állampolgárságot 
nem elfogadó Kína számára, hogy megoldást találjon arra, miként tudná mégis az állampolgárainak járó jogokat a korábban kivándorolt kínaiak számára úgy biztosítani, hogy eközben abból másokat kirekeszt. Mindezen törekvések egyúttal a befogadó országok szemléletét is megváltoztatják. Minél jobban törekszik Kína a határon túl élôket bevonni a gazdasága növelése céljából, annál inkább tekintenek a szomszédos országok úgy az ott élő kínai kisebbségekre, mint Kína „kinnlevőségeire”, s ez befolyással van az ó hozzáállásukra és kisebbségi politikájukra is. Kína számára persze valóban ugyanolyan eszközt jelent a diaszpóra, mint bármilyen más erôforrás, ami segítheti a gazdasági növekedést, a jólétet, és nem utolsósorban erôsítheti a hatalmát s az abból fakadó nemzetközi helyzetét (Roy, 1998:215).

Visszatérne tehát a geopolitikai séma a múltból? Vegyük példaként azt a Nagy-Kína-koncepciót, mely a gazdasági térnyerés eszközéül tekinti Hongkongot, Makaót, de legalább ennyire Tajvant és a délkelet-ázsiai kínai tőkét, sôt, melynek érdeklődése akár azon túl terjedhet. A hetvenes évek óta megindult gazdasági nyitás egyre szorosabbá tette a fenti közösségekhez fúzôdô kapcsolatokat, s Hongkong egyre inkább Kína kapujává vált. A nyolcvanas évektől kezdve azonban mind Hongkong, mind Tajvan fokozatosan kiszorult a termékeivel a kínai piacokról, különösen annak délkeleti tartományaiban, Kuangtungban, Fucsienben és Csöcsiangban gyorsan terjedô gyáripara miatt (Golley, 2002). Ez a változás kényszerítette óket arra, hogy gazdasági irányvonalukat a szolgáltatás és a fejlett technológia irányába tereljék, s így a piaci kapcsolataikat Kínával továbbra is fenntarthassák. Az egyre szorosabbá váló gazdasági integráció mindazonáltal növekvố aggodalmat is kivált Tajpejben, hiszen ez egyben lehetôséget adhat a kínai politikai befolyás növekedésére is. Mindez mégsem gátolja a kapcsolatok fejlôdését, annál sokkal erôsebb a gazdasági szempont, s erról nem csupán az érintett országok politikája gyốz meg minket, hanem a nemzetközi vélemény is egybecsengô (Lanteigne, 2009:42).

De Kínának más problémákkal is meg kell küzdenie, ha a „külföldi tôkét” akarja látni határon túli fiaiban. A beáramló tôke nyolcvan százalékát a kilencvenes évekre ugyanis valóban ốk hozták az országba, ám ezzel együtt érkezett a kozmopolita, pluralista szemléletük is, ami már jóval kevésbé volt ínyére a politikai autoritás kikezdhetetlenségét szem elôtt tartó állami érdekeknek (Segal, 1995:68-69). A szövevényes okozati rendszerben tehát Kínának a határon túl élőkkel kapcsolatos érdekei szükségszerúen kiterjedtek a gazdasági mellett a kulturális és politikai területekre is. A hazautalások és tôkebefektetések mellett tehát a diaszpórapolitika foglalkozik már a kínai nyelv és kultúra határon túli ápolásával is, s mindezzel annak terjesztésére, Kína befolyásának növelésére is hatással van.

De nézzünk kicsit bele, hogy milyen gazdasági eszközrôl is van szó. A World Bank becslése szerint a 2015. évi hazautalások összege Kínába 63899 millió dollár volt, amit csak India elôzött meg a világon (The World Bank, 2016:97). Csupán a kilencvenes évek második felében több mint háromezer vállalkozást alapítottak a kínai kivándorlók a kormány segítségével Kína különbözô gazdasági fejlesztési övezeteiben (Barabantseva, 2012a:123). A Különleges Gazdasági Övezeteket részben éppen azért is hozták létre az 1979-es gazdasági nyitás után, hogy az elvándorolt kínaiak beruházá- 
sainak infrastrukturális kereteket teremtsenek, s éppen azért azokban a déli tartományokban, mert a zömük onnan származott. Ezek nem mellékesen mind közel fekszenek Hongkonghoz, Makaóhoz és Tajvanhoz. Miután a saját gazdasági autonómiával rendelkezô területek rendkívül jó ötletnek bizonyultak, és a nyolcvanas években a közvetlen külföldi tốkebefektetések hatvan százalékát adták, a kormány egyre többet hozott létre a nagyon eltérô jellegú, néhol városra, néhol egész tartományra kiterjedó övezetekből, melyek kezdtek földrajzilag egyre inkább a kontinens belsejébe irányulni. 2010-ben már 69 ilyen múködött Kínában, beleértve annak ágazatilag specifikált formáit is (Zeng, 2012:5-7). A kezdetektôl külön engedmények voltak érvényesek a diaszpóra számára: a lakhatás biztosítása, kutatási alapok, valamint különleges oktatási, ellátási és szállítási támogatások. Különösen igaz volt ez a Gyöngy-folyó deltájának környékén létrehozott övezetekre, Tungkuanra, Huizhoura és Sencsenre, melyek közelsége Hongkonghoz, mint említettük, szintén kiválasztási szempont volt (Wang-Yue, 2010). Mindazonáltal elhibázott volna azt hinni, hogy a kínai politika valaha is szabad utat engedett a kapitalizmusnak, akár csak a Különleges Gazdasági Övezetekben is. A kormány egy sor korlátozó szabályozást hívott életre, melyek célja a külföldi és hazai folyamatok ellenốrzése, a bürokrácia segítése volt. A közigazgatási egységek jogi intézményei korlátozták a hazai gazdasági érdekek globális tranzakciókba való bekapcsolódását, így tehát korántsem beszélhetünk szabadpiacról (Zweig, 2001:31).

A kínai származású befektetốk és a kormányhivatalok között egyfajta szinergia alakult ki (Lever-Tracy-Ip, 1996). Természetesnek túnik egyfelól, hogy a közös kulturális háttér, nyelv vagy akár az identitás segítheti a gazdasági együttmúködést; így a hongkongi vagy tajvani befektetôknek, vagy akár a délkelet-ázsiai kínaiaknak sokkal könnyebb dolguk volt Kínában, mint az amerikai vagy európai vállalkozóknak, akár még a politikai ellentéteken is képesek voltak felülemelkedni. Ez azonban csak részben igaz; a fenti szemlélet ugyanis figyelmen kívül hagyja a kínai társadalmon belüli egyenlốtlenségeket, illetve a szolidaritás és a gazdasági érdek esetleges ellentmondásait. Nem is beszélve arról a következményről, melyben a túlzott társadalmi kötődések elnyomják az eredeti gazdasági motivációkat, vagyis hogy egy esetleges könnyítés késôbb akadállyá változik, és ezzel magát a gazdasági kapcsolatháló múködését lehetetleníti el (Smart-Hsu, 2004:543). Már az ezredfordulóra nyilvánvalóvá vált, hogy ahol a határokon átnyúló etnikai kapcsolathálók felülírják a primer gazdasági érdekeket, ott a vállalkozások kevésbé hatékonyak, mint másutt (Guthrie, 1998). A délkelet-ázsiai országok nem is nézték jó szemmel a pénzmozgások ilyetén ellenôrizetlen voltát, és a megfigyelés és ellenőrzés növekedésével egyre csökkent a beruházási kedv is (Garver, 2016:378-379). Kína WTO-tagsága is hasonló következményekkel járt, amennyiben a gazdaságirányítás egyre rutinszerúbbé vált a népköztársaságban.

A Kínai Államtanács felkérésére 2007-ben a Csinghua Egyetem professzora, Long Denggao vezetésével egy kutatócsoportot állítottak fel abból a célból, hogy a kínai diaszpóra közvetlen tốkebefektetéseit feltérképezzék Kínában. Kétévi munka után sikerült egy megfelelốn részletes adatbázist felépíteniük, melyból kiderült, hogy az országban múködő 298 ezer vállalkozásból hetvenezer jött létre ily módon, összesen 400 milliárd dollár befektetéssel. Az adatbázisba ráadásul csak a legalább huszonöt 
százalék emigráns-tulajdonrésszel rendelkezô vállalkozások kerültek be, és egyáltalán nem szerepelnek a tajvani beruházások. Hatvan százalékuk még így is hongkongi és makaói tőke, melyet a Gyöngy-folyó deltavidékén, míg az európai és latin-amerikai diaszpóra tôkéjét a Jangce deltájának vidékén fektették be, a délkelet-ázsiai emigránsok pedig szerte az országban hoznak létre üzleteket (Cheung, 2012:87). Mindez ugyanakkor nem mellékes szempont Kína Hongkonggal kapcsolatos politikájának megértésénél sem.

\section{Ös S ZEGZÉS}

Habár a kínai diaszpóra nem a legnagyobb a világon, annak anyaországhoz fúzôdô viszonya különleges, sôt mintaadó más országok diaszpórapolitikája számára is. Ennek oka azonban igen szerteágazó: részben közrejátszik, hogy más közösségekkel szemben évezredes múltra tekint vissza, részben pedig az, hogy a befogadó országokba való beilleszkedése sokszor jóval nehezebben ment, ami az integráció rovására, ám az identitás megőrzésének javára szolgált. Kína a császárság késô időszakától kezdve tudatosan kereste a kapcsolatokat az országon kívül élókkel, s akkor is csupán külföldön élôkként értelmezte helyzetüket, amikor azok már generációk óta éltek ott. Kína ugyanis hagyományosan nem támogatta polgárai elvándorlását az ország területéról. Már a Ming-dinasztia idején léteztek törvények, melyek a kereskedelem korlátozásához köthetốen kiterjedtek a kivándorlás egészére, noha ezek akkor még elsôsorban a technológiát, innovációkat védték. A Csing-dinasztia azonban fokozatosan minden kapcsolódó tevékenységet betiltott, és a 19. századi nyugati igény egyik legfontosabb eleme az ópiumháborúk után éppen az volt, hogy kikényszerítette a munkaerô-kivitel engedélyezését. Ez elengedhetetlenül szükséges forrásnak bizonyult a rabszolga-kereskedelem már említett megszúnése után, és a Nankingi-szerzôdés tartalmazott is egy passzust erról, ám törvényi formát csak 1893-ban öltött (Wang, 2000:46).

Mára a népköztársaság és a diaszpóra kapcsolata elsôdlegesen a hazavándorlást célozza, ám azon túl is egyre inkább a tôke hazai befektetését, ezzel is gazdasági potenciált keresve. Az állam ilyen irányú tevékenysége mind ennek árnyékában történik, beleértve a kultúrpolitikát, nyelvtanítást és a vonatkozó bilaterális kapcsolatokat is. Kína diaszpórapolitikája azonban nem csupán gazdasági racionalitást tükröz, hanem történelmi örökség is egyben. Egy olyan han-centrikus világkép mutatkozik meg múködésében, mely a területi integritás megôrzése és megerôsítése mellett egyfajta sajátos, kulturális gyökereken nyugvó, ám mégis modern, határok nélküli nemzetállami konstrukciót sugall.

\section{JEGYZETEK}

1 Nem szükségszerúen használja következetesen a fogalmakat minden kutató. Gungwu Wang (1993:926) jeles ausztrál történész pl. a külföldi kínaiakra az „overseas Chinese” kifejezést használja a diaszpóra értelemben, illetve az idézett könyvében.

2 A fentiek 50 millióra teszik, míg Barabantseva (2005:1) 30 millióra becsüli a kínai diaszpóra számát. 


\section{Koudela Pál: A kínai diaszpóra}

\section{FELHASZNÁLT IRODALOM}

Barabantseva, Elena (2005): The Party-State's Transnational Outreach: Overseas Chinese Policies of the PRC's Central Government. In: Greater China Occasional Paper Series, no. 2. Institute of Chinese and Korean Studies, University of Tubingen.

Barabantseva, Elena (2012a): Overseas Chinese, Ethnic Minorities and Nationalism. De-Centering China. Routledge, London.

Barabantseva, Elena (2012b): Who Are "Overseas Chinese Ethnic Minorities"? China's Search for Transnational Ethnic Unity. Modern China, vol. 38, no. 1., 78-109., https://doi.org/10.1177/0097700411424565.

Baviera, Aileen S. P. (2012): The Influence of Domestic Politics on Philippine Foreign Policy: The case of Philippines-China relations since 2004. RSIS Working Paper, vol. 14, no. 241., 1-36.

Brubaker, Rogers (2005): The 'Diaspora' Diaspora. Ethnic and Racial Studies, vol. 28, no. 1., 1-19., http:// dx.doi.org/10.1080/0141987042000289997.

Charney, Michael W. - Yeoh, Brenda S. A. - Tong, Chee Klong (eds.) (2003): Chinese Migrants Abroad. Cultural, Educational, and Social Dimensions of the Chinese Diaspora. World Scientific Publishing, Singapore.

Chen, Min (2004): Asian Management Systems. Chinese, Japanese and Korean Styles of Business. Thomson, London.

Cheung, Gordon C. K. (2012): The Significance of the Overseas Chinese in East Asia. In: Routledge Handbook of Asian Regionalism. Eds. Mark Beeson, Richard Stubbs, Routledge, London, 77-89., https://doi. org/10.4324/9780203803608.ch6.

China Daily (2005): Thai PM seeks out roots in Meizhou. China Daily, www.chinadaily.com.cn/english/ doc/2005-07/04/content_456688.htm (Letöltés: 2016.június 29.).

China Daily (2012): Hu meets overseas Chinese organizations leaders. China Daily, 9Apri. április 9., www. chinadaily.com.cn/china/2012-04/09/content_15007664.htm (Letöltés: 2016. július 4.).

Christiansen, Flemming (2003): Chinatown, Europe. An Exploration of Overseas Chinese Identity in the 1990s. Routledge Curzon, London.

Ding Media (2016): 40 million Chinese diaspora abroad can now instantly transfer airtime via Ding. Ding Media Center, 30 May, http://media.ding.com/press-release/2016/5/30/40-million-chinese-diasporaabroad-can-now-instantly-transfer-airtime-via-ding (Letöltés: 2016. július 4.).

Freedman, Amy L. (2000): Political Participation and Ethnic Minorities. Chinese Overseas in Malaysia, Indonesia, and the United States. Routledge, New York.

Garver, John W. (2016): China's Quest. The History of the Foreign Relations of the People's Republic of China. Oxford University Press, Oxford, https://doi.org/10.1093/acprof:oso/9780190261054.001.0001.

Golley, Jane (2002): Regional patterns of industrial development during China's economic transition. Economics of Transation, vol. 10, no. 3., 761-801., https://doi.org/10.1111/1468-0351.t01-1-00133.

Guthrie, Douglas (1998): The Declining Significance of Guanxi in China's Economic Transition. The China Quarterly, no. 154., 254-282.

Huisken, Ron (2016): The Outlook for Security in the Asia Pacific: Uncertain. In: Regional Security Outlook. Ed. Ron Huisken, Council for Security Cooperation in the Asia Pacific, Canberra, 3-7.

Indonesia Diaspora Network (2016): About Diaspora. www.diasporaindonesia.org/index.php/about/diaspora internetrôl (Letöltés: 2016. június 13.).

Kao, John (1993): The Worldwide Web of Chinese Business. Harvard Business Review, vol. 93, no. 2., 24-36.

Kenley, David L. (2003): New Culture in a New World. The May Fourth Movement and the Chinese Diaspora in Singapore, 1919-1932. Routledge, New York.

Koudela, Pál (2013): A Brief History of Immigration Policy in the United States. West Bohemian Historical Review, vol. 3, no. 2., 43-65.

Kuah-Pearce, Khun Eng - Davidson, Andrew P. (eds.): (2008): At Home in the Chinese Diaspora. Memories, Identities and Belongings. Palgrave Macmillan, New York.

Kurlantzick, Joshua (2007): Charm Offensive. How China's Soft Powers Transforming the World. Yale University Press, New Haven.

Lanteigne, Marc (2009): Chinese Foreign Policy. An Introduction. Routledge, London, https://doi.org/ $10.4324 / 9780203881217$. 
Lever-Tracy, Constance - Ip, David - Tracy, Noel (1996): The Chinese Diaspora and Mainland China. An Emerging Economic Synergy. Palgrave Macmillan, Houndmills.

Lim, Walter S. H. (2013): Narratives of Diaspora Representations of Asia in Chinese American Literature. Palgrave Macmillan, New York, https://doi.org/10.1057/9781137055545.

Liu, Guofu - Du, Zejun (2014): The People's Republic of China Policy and Institutional Frameworks, National Report. Interact Research Report 2014/19, European University Institute Robert Schuman Centre for Advanced Studies.

Liu, Haiming (2002): Historical Connections between the Chinese Trans-Pacific Family and U.S.-China Relations. In: The Expanding Roles of Chinese Americans in U.S.-China Relations. Transnational Networks and Trans-Pacific Interactions. Eds. Peter H. Koehn, Xiao-huang Yin, M.E. Sharpe, Armonk, 3-19.

Muhidin, Salut - Utomo, Ariane (2013): How many overseas Indonesians are there? Discussion Paper Series, no. 1/2013, Indonesia Diaspora Network.

Nyíri Pál (2003): Új ázsiai migráció Kelet-Európába: a magyarországi kínaiak. In: Tér és Terep. Tanulmányok az etnicitás és az identitás kérdéskörébôl II. Szerk. Kovács Nóra, Szarka László, Akadémiai Kiadó, Budapest, 161-181.

Pan, Lynn (1990): Sons of the Yellow Emperor. A History of the Chinese Diaspora. Secker \& Warburg, London.

Phongpaichit, Pasuk - Baker, Christopher John (2004): Thaksin. The Business of Politics in Thailand. NIAS Press, Copenhagen.

Poston, Dudley L. Jr. - Luo, Hua (2007): Chinese Student and Labor Migration to the United States: Trends and Policies since the 1980s. Asian and Pacific Migration Journal, vol. 16, no. 3., 323-355., https://doi. org/10.1177/011719680701600302.

Poston, Dudley L. Jr. - Yu, Mei-Yu (1990): The Distribution of the Overseas Chinese in the Contemporary World. International Migration Review, vol. 24, no. 3., 480-508.

Poston, Dudley L. Jr. - Wong, Juyin Helen (2014): The Chinese Diaspora Population in circa-2011. Presented in Poster Session 4: Migration and Urbanization; Population, Development and the Environment, Population Association of America, 2014 Annual Meeting Program.

Potter, Pitman B. (2007): Theoretical and Conceptual Perspectives on the Periphery in Contemporary China. In: The Chinese State at the Borders. Ed. Diana Larry, University of British Columbia Press, Vancouver, 240-270.

Putzel, James (1992): A Captive Land. The Politics of Agrarian Reform in the Philippines. Monthly Review Press, New York.

Rae, Ian - Witzel, Morgen (2008): The Overseas Chinese of South East Asia. History, Culture, Business. Palgrave Macmillan, Houndmills, https://doi.org/10.1057/9780230593121.

Xinhua (2012): Reforms urged to attract overseas Chinese. Xinhua, 11 March, www.china.org.cn/china/ NPC_CPPCC_2012/2012-03/11/content_24865428.htm (Letöltés: 2016.július 4.).

Rigger, Shelley (2014): Taiwan. In: Politics in China. An Introduction. Ed. William A. Joseph, Oxford Univerity Press, Oxford, 468-485.

Roy, Denny (1998): China's Foreign Relations. Rowman \& Littlefield, Boulder, https://doi.org/10.1007/9781-349-26364-6.

Safran, William (1991): Diasporas in modern societies: Myths of homeland and return. Diaspora, vol. 1, no. 1., 83-99., https://doi.org/10.1353/dsp.1991.0004.

Segal, Gerald (1995): Tying china into the international system. Survival, vol. 37, no. 2., 60-73., http:// dx.doi.org/10.1080/00396339508442790.

Sherwood, Marika (2007): After Abolition. Britain and the Slave Trade since 1807. I. B. Tauris, London.

Skard, Torild (2015): Women of Power: half a century of female presidents and prime ministers worldwide. Policy Press, Bristol.

Smart, Alan - Hsu, Jinn-yuh (2004): The Chinese Diaspora, Foreign Investment and Economic Development in China. The Review of International Affairs, vol. 3., no. 4., 544-566.

Tan, Chee-Beng (ed.) (2012): Routledge Handbook of the Chinese Diaspora. Routledge, Abingdon, https://doi. org/10.4324/9780203100387.

To, James Jiann Hua (2014): Qiaowu. Extra-Territorial Policies for the Overseas Chinese. Brill, Leiden. 


\section{Koudela Pál: A kínai diaszpóra}

Wang, Gungwu (1993): Greater China and the Chinese Overseas. The China Quarterly, vol. 136, no. 30., 926-948., https://doi.org/10.1017/S0305741000032392.

Wang, Gungwu (2000): The Chinese Overseas. From Earthbound China to the Quest for Autonomy. Harvard University Press, Cambridge.

Wang, Gungwu (2003): China and the Chinese Overseas. Eastern University Press, Singapore.

Wang, Huiyao (2012): China's Competition for Global Talents: Strategy, Policy and Recommendations. Research Report, Asia Pacific Foundation of Canada.

Wang, Jun - Yue, Fangmin (2010): Cluster development and the role of government: The case of Xiqiao textile cluster in Guangdong. In: Building Engines for Growth and Competitiveness in China. Ed. Douglas Zhihua Zeng, The World Bank, Washington, 181-219.

Weidenbaum, Murray L. - Hughes, Samuel (1996): The Bamboo Network. How Expatriate Chinese Entrepreneurs are Creating a New Economic Superpower in Asia. Simon and Schuster, New York.

Woody, Christopher (2016): The Philippines' president is headed to China with high hopes, but he may be in for a rough landing. Business Insider, 19 October, www.businessinsider.com/philippines-rodrigoduterte-trip-to-china-expectations-and-dangers-2016-10 (Letöltés: 2016. november 3.).

The World Bank (2016): Migration and Remittances Factbook 2016. The World Bank, Washington.

Xinhuanet (2016): Interview: Philippine president says „only China can help us”. Xinhuanet, http://news. xinhuanet.com/english/2016-10/17/c_135760893.htm (Letöltés: 2016. november 3.).

Yong, Ching-Fatt (2014): Tan Kah-kee. The Making of an Overseas Chinese Legend. World Scientific Publishing, Singapore.

Zeng, Douglas Zhihua (2012): China's Special Economic Zones and Industrial Clusters: the Engines for Growth. Journal of International Commerce, Economics and Policy, vol. 3, no. 3., 1-28., https://doi. org/10.1142/S1793993312500160.

Zhu, Guobin (2012): The composite state of China under "One Country, Multiple Systems": Theoretical construction and methodological considerations. International Journal of Constitutional Law, vol. 10, no. 1., 272-297., https://doi.org/10.1093/icon/mos005.

Zweig, David (2001): Internationalizing China. Domestic Interests and Global Linkages. Cornell University Press, Ithaca. 